\title{
Are the wing's cells alive? Study case in Vriesea trichomes
}

\author{
As células da ala são vivas? Estudo de caso em tricomas de Vriesea
}

\author{
Vanessa Koza Kowalski ${ }^{1,2}$, Pamella Paula Diniz Alves Pereira ${ }^{1}$, Fernanda Maria Cordeiro de Oliveira ${ }^{1}$, \\ Maria Eugênia Costa $^{1}$ \& Rosangela Capuano Tardivo ${ }^{1}$
}

\begin{abstract}
The presence of peltate foliar trichomes is one of the main anatomical characteristic of Bromeliaceae. These complex structures are adapted to compensate water and nutrient absorption in species that have reduced or substrate and light-reflection independent roots. They have enabled species' survival in diverse and extreme environments contributing to the wide distribution of this family. In the present work, we analyzed the peltate trichomes' characteristics in three taxa of Vriesea (Tillandsioideae): Vriesea platynema var. platynema, $V$. platynema var. variegata and $V$. tijucana. Leaves in different developmental stages were analyzed with histochemical tests and Transmission Electron Microscopy. Main results include the presence of cytoplasmic content in the wing peripheral cells, as well as in mature leaves. This is the first register of the presence of such feature in this family, which brings the possibility of discussing how water can be absorbed by these cells.
\end{abstract}

Key words: Anatomy, Tillandsioideae, absorptive trichomes.

\section{Resumo}

Uma das principais características anatômicas de Bromeliaceae é a presença de tricomas foliares peltados. Estas complexas estruturas adaptadas à compensação da absorção de água e alimento em espécies com raízes reduzidas ou independentes do substrato e reflexão da luz, possibilitaram a vida em ambientes diversos e extremos, contribuindo para a ampla distribuição desta família. Neste estudo são analisadas as características dos tricomas peltados de três espécies do gênero Vriesea (Tillandsioideae): Vriesea platynema var. platynema, V. platynema var. variegata e V. tijucana. Folhas em diferentes fases de desenvolvimento foram analisadas com testes histoquímicos e de Microscopia Eletrônica de Transmissão. Destacam-se a presença de citoplasma evidente em células periféricas da ala, inclusive em folhas maduras, característica esta, inédita evidenciada pela primeira vez para a família, possibilitando a discussão da absorção de água por estas células.

Palavras-chave: Anatomia, Tillandsioideae, tricomas absorventes.

\section{Introduction}

Bromeliaceae Juss. is one of the most striking families in the tropical forests of the American continent (Benzing 2000; Martinelli et al. 2008). It comprises 58 genera and 3,352 currently known species (Luther 2012), which are distributed in three major regions: the Atlantic Forest along the eastern coast of Brazil, the Guyana Highlands, and from the northern Andes to Mexico and the Antilles. Evolutionary aspects, such as leaves arranged in a rosette enabling rainwater capture and storage, as well as the absorptive trichomes in leaves have enabled survival in diverse and extreme environments, contributing to the wide distribution of the family (Benzing 2000).

Hypotheses on the evolution of epiphytism in Bromeliaceae, which is mainly observed in Tillandsioideae have been put forth by a number of authors. According to Schimper (1888), epiphytes evolved from terrestrial species found in rainforests growing apart from their usual source of water, the soil. Tietze (1906) states that the likely ancestor of Bromeliaceae would be a xerophytic plant, similar to the species of Pitcairnioideae. This

\footnotetext{
${ }^{1}$ Universidade Estadual de Ponta Grossa, Campus Uvaranas, Av. General Carlos Cavalcanti 4748, 84030-900, Ponta Grossa, PR, Brazil.

${ }^{2}$ Author for correspondence: vanessakkowalski@gmail.com
} 
subfamily has foliar trichomes that potentially perform the function of absorbing water given their contact with the mesophyll, despite a low degree of organization. In contrast, trichomes in Bromelioideae and Tillandsioideae have a greater degree of organization and constitute an efficient water and nutrient absorption system. The hypothesis proposed by Pittendrigh (1948) is in partial agreement with the one proposed by Tietze (1906), in which the likely ancestor is a terrestrial plant from dry environments. However, the ascendance to Pitcairnioideae suggested by Tietze (1906) is doubtful. Pittendrigh (1948) suggests that formation of the leaf rosette is involved in water and humus capturing through the leaves' bases and states that the absorbent foliar trichome system has enabled the existence of epiphytic species in Bromeliaceae.

Anatomically, Bromeliaceae has typical characteristics such as: epidermal cells with sinuous walls containing silica bodies (Smith \& Downs 1974; Tomlinson 1969), and peltate trichomes on the leaves which are adapted to water and nutrient absorption in species with short roots and roots that do not depend on substrate or light reflection. The latter is considered to be an apomorphic feature for the family (Gilmartin \& Brown 1987).

The pedicel connects the trichomes to the remaining epidermis and the wing in order to capture and transport water and nutrients. The wing is positioned in parallel to the leaf surface and is composed of a central disc and a peripheral wing, which vary in number and position according to each subfamily in response to the evolutional pattern (Strehl 1983).

Anatomical studies in Bromeliaceae have been carried out with different goals, such as the characterization of its subfamilies, the understanding of the plant-environment relationship and taxonomic classifications.

Specific studies addressing absorbent peltate trichomes have been conducted since the $19^{\text {th }}$ century traditionally analyzing three subfamilies: Bromelioideae, Pitcairnioideae and Tillandsioideae. Mez (1896) accounts the structure of trichomes and Krauss (1949) detailed their ontogeny, but neither of them pointed out details of cell's content. Tomlinson (1969), Benzing (1976), Braga (1977) and Strehl (1983) have detailed the structure, the number and the shape of cells. These authors have described the structure of wing cells, also known as shield cells, to be dead, losing cell content when trichomes reach their full developed. These authors have also described the basal stalk and the domecells with densely cytoplasmic contents. Recently, studies elaborated by Proença \& Sajo (2004, 2007); Mantovani \& Iglesias (2005); Scatena \& Segecin (2005); Souza, Estelita \& Wanderley (2005); Pereira et al. (2011); Silva \& Scatena (2011); and Silva, Oliveira \& Scatena (2011) described the trichome structure in different genera of Bromeliaceae, but made no reference to either the presence or absence of content within the cells.

Considering the works mentioned above, the present study aimed to describe the structure of peltate trichomes in three taxa of Vriesea Lindl. (Tillandsioideae): Vriesea platynema Gaudich. var. platynema, $V$. platynema var. variegata (Guillon) Reitz, and V. tijucana E. Pereira, offering a discussion on the cytoplasmic content in the wings' peripheral cells of the peltate trichomes in Bromeliaceae.

\section{Material and Methods}

The taxa analyzed here are all epiphytic ones. They bear their leaves arranged in a rosette that forms a basal tank for capturing water and nutrients. Sampling was carried out at different sites in Paraná State (Brazil), comprising regions of mixed rainforest, dense rainforest and grasslands. Part of the sampled material was deposited at the Herbarium of Universidade Estadual de Ponta Grossa (Brazil) under the following numbers: Vriesea platynema Gaudich. var. platynema ( $V$. Kowalski 22, 58, 59), Vriesea platynema var. variegata (Guillon) Reitz (V. Kowalski 09, 28, 34 ), and Vriesea tijucana E. Pereira (V. Kowalski $17,48,55)$. The remaining material was fixed in formaldehyde-ethanol-acetic acid 50\% $\left(\mathrm{FAA}_{50}\right)$ for 24 hours (Johansen 1940) and stored in 70\% ethyl alcohol. In addition, living plants were cultivated for histochemical tests.

Three plants of each species were selected from different sites as a means to ensure the analysis of individuals with different genotypes. According to their position within the rosette, young, mature and old leaves were selected and sectioned at the half portion of the leaf blade and also at the half portion of the leaf sheath.

Paradermal, transverse and longitudinal sections were produced by free hand sectioning using razor blades. The sections were stained with safranin, basic fuchsine, Astra blue and Toluidine Blue (Kraus \& Arduin 1997). Glycerinated gelatin was used as the mounting medium (Kaiser 1880). 
The sections were submitted to histochemical analysis with phloroglucin solution in an acid medium for the detection of lignin (Berlyn \& Miksche 1976). Parts of fresh samples were submitted to the tetrazolium test in order to determine the vitality of the peltate trichomes' wing cells. The tetrazolium test indicates the presence of living tissue by binding to respiration enzymes inside these cells. When in contact with tetrazolium, these enzymes produce trifenilformazan, which gets colored in red (Brasil 2009). For this test the leaf sheath was lightly scraped with the aid of a razor blade. Along with the transverse and paradermal sections (Brasil 2009), the material was bathed in a $1 \%$ tetrazolium solution and maintained in an incubator at $30^{\circ} \mathrm{C}$ for 24 hours. In order to produce control slides, the same procedure was carried out without the addition of the reagent.

Another portion of the fresh material was submitted to Evan's Blue solution (Baker \& Mock 1994). In case of vacuolization and membrane rupture, this stain permeates through the disrupted plasma membrane, thus coloring the interior of the cell in blue (Baker \& Mock 1994).

A third part of the fresh material was submitted to Neutral Red solution, a vital dye that passes through the cell membrane and reacts with lysosomes. If the membrane cell is damaged the dye cannot enter the cell and reacts with lysosomes (Ruzin 1999).

All slides were mounted with distilled water. They were analyzed under a light microscope and photographed with a digital camera (Olympus, CX21 series) coupled to the microscope.

For the analysis using Scanning Electron Microscopy (SEM), the material was previously fixed in glutaraldehyde and stored in alcohol $50 \%$. Subsequently the material was dehydrated in increasing concentrations of ethanol, submitted to $\mathrm{CO}_{2}$ critical point and gold sputtered in vacuum. The analyses were performed using the SSX-550 scanning electron microscope at the Department of Material Engineering, at Universidade Estadual de Ponta Grossa.

For the analysis using Transmission Electron Microscopy (TEM), the material was previously fixed in $1 \%$ glutaraldehyde in $0.1 \mathrm{M}$ phosphate buffer for 24 hours and post-fixed in $1 \%$ osmium tetroxide $\left(\mathrm{OsO}_{4}\right)$ in the same buffer for two hours. Subsequently the material was dehydrated in ethanol/acetone series and embedded in Spurr's epoxy resin (Spurr 1969). Semithin sections $1 \mu \mathrm{m}$ thick were cut for light microscopy with a Reichert
Ultracut S microtome and stained with Toluidine Blue (O'Brien et al. 1964). Ultrathin sections were stained with uranyl acetate (Gibbons \& Grimstone 1960) followed by lead citrate (Reynolds 1963). The material was analyzed using Zeiss EM900 microscope at the Microscopy Center of the University of São Paulo.

\section{Results}

Although we analyzed three different stages of expanded leaves, we did not find different results regarding the trichome structure in each taxa. The trichomes were observed to be partially lined in the analyzed leaves of Vriesea. Regarding the trichome distribution, they were unevenly distributed on both faces of the sheath and organized between the bundles on the leaf blade.

The trichomes are peltate and made up of a wing that is attached to a depression in the leaf epidermis by a multicellular pedicel and two basal cells. In frontal view, the wing shows a regular shape and is composed of three concentric rings: a central ring, with four cells; a pericentral ring, with eight cells; and a symmetrical ring, with radially arranged elongated peripheral cells (Fig. 1a). The walls of the central and pericentral cells are uniformly thin (Figs. 1b,d,f). The walls of the wing cells are generally thick. Although, these wall are thin in the region adjacent to the pericentral cells resembling conspicuous pits (Figs. 1b,d,f). The walls of these cells were slightly stained by fuchsine, but they did not react with phloroglucin. One possible explanation to this selective staining would be that the fuchisine could have reacted with the polysaccharides present in the wing cell's wall.

In Vriesea tijucana, the wing of the trichomes has a peacock-tail-like appearance, as the walls exhibit an abrupt thinning in the median or basal portion, rendering a rounded appearance to this region (Fig. 1g). The cytoplasmic content is evident in these cells (Figs. 1d,e). On the other hand, the wing cells of the trichomes in $V$. platynema var. platynema and $V$. platynema var. variegata do not exhibit this feature (Figs. $1 \mathrm{~b}, \mathrm{~d})$. Cytoplasmic content is also evident for all three taxa in some central and pericentral cells as observed in longitudinal view (Figs. 1c,e,h). The wing comprises a variable amount of cells; the approximate amount observed were 54, 64 and 74 in $V$. tijucana, $V$. platynema var. platynema and $V$. platynema var. variegata, respectively (Figs. 1b,d,f). 

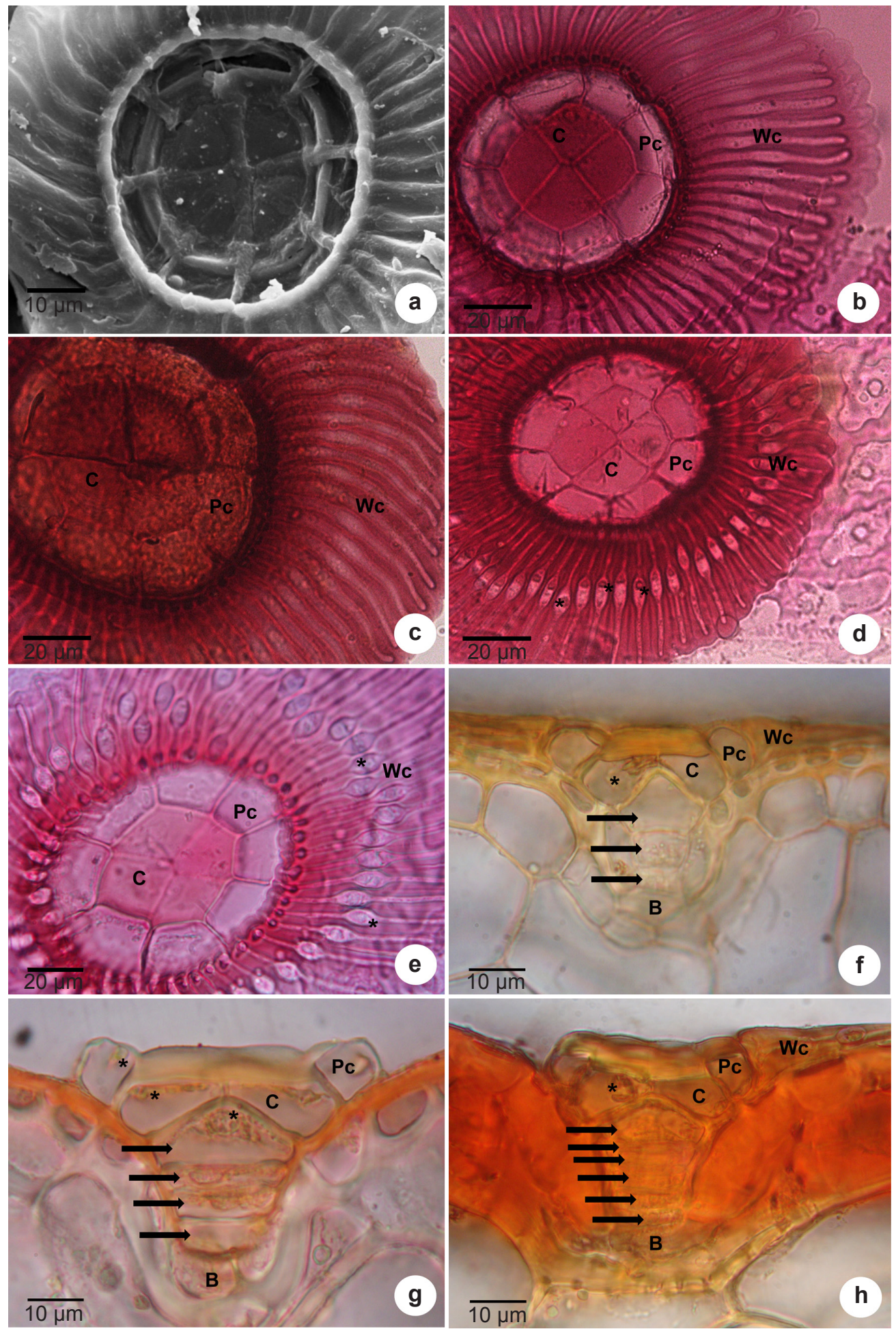

Figure 1 - Trichomes - a-c. Vriesea platynema var. variegata (Guillon) Reitz-a. SEM; b. Front view of trichome; c. longitudinal section of trichome. d-e. Vriesea platynema Gaudich. var. platynema- d. Front view of trichome; e. longitudinal section of trichome. f-h. Vriesea tijucana E. Pereira- f. Front view of trichome; g. Front view of trichome, highlighting cytoplasmic content; h. longitudinal section of trichome. $\mathrm{B}=$ basal cells; $\mathrm{C}=$ central cells; $\mathrm{Pc}=$ pericentral cells; Wc = wing cells; asterisks indicate cytoplasmic content $(\mathrm{c}, \mathrm{e}-\mathrm{h})$; arrows indicate cells of pedicel (c,e,h). 
Considering the histochemical tests, the same result was obtained for the three stages of expanded leaves (young, mature and old leaves) in all three taxa. The tetrazolium test showed that these cells are weakly stained red, which indicates these cells are actually alive (Fig. 2a).
The reaction with neutral red showed these cells strongly colored in red, thus corroborating the result of tetrazolium test (Figs. 2b,e). A further corroboration was obtained by submitting paradermical sections to Evan's Blue reagent, once no reaction was observed between the reagent and
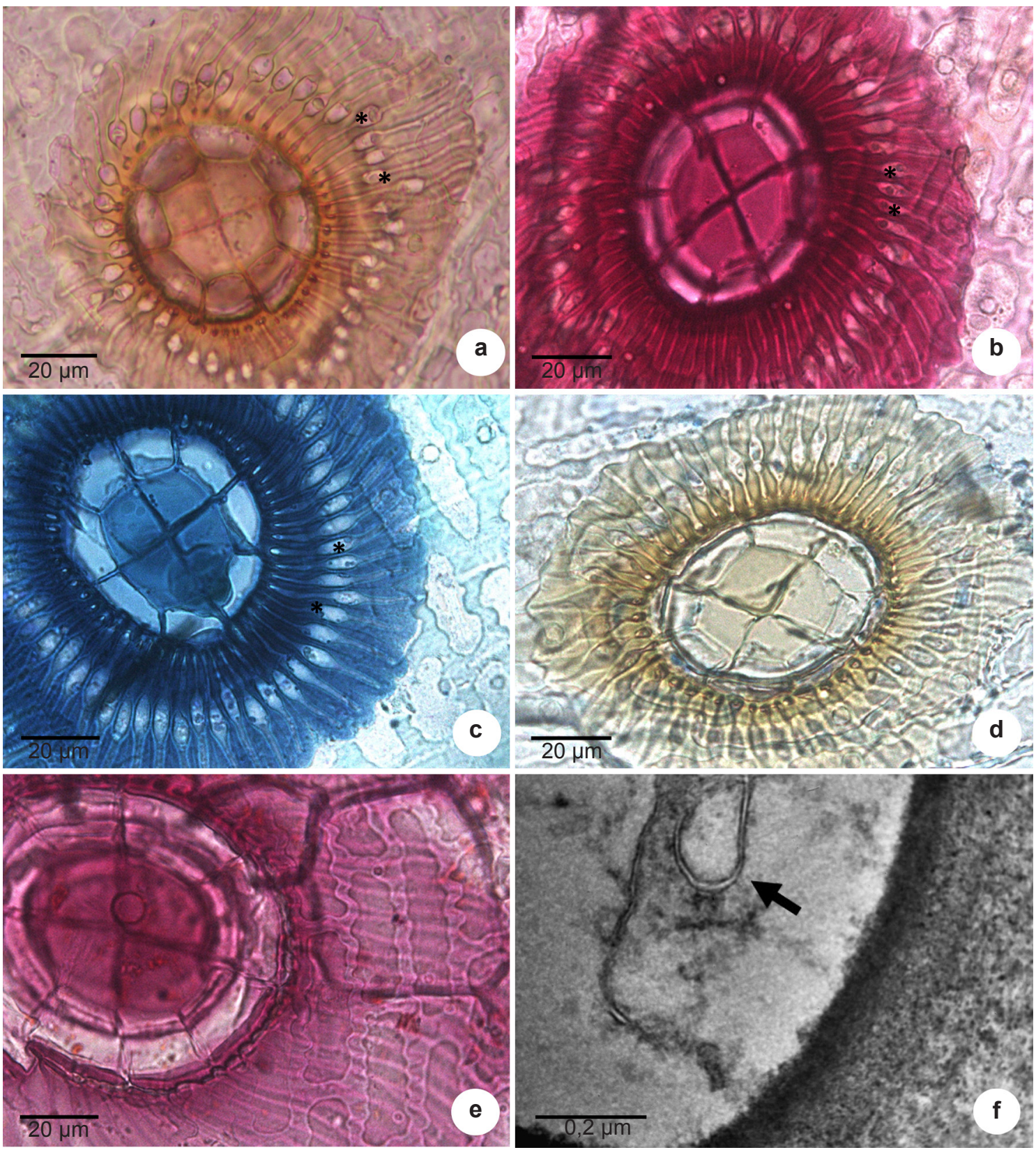

Figure 2 - Histochemical analysis, front view of trichomes - a-d. Vriesea tijucana - a. tetrazolium test; b. neutral red test; c. Toluidine Blue test; d. Evan's Blue test. e-f. Vriesea platynema var. platynema - e. neutral red test; f. transmission electron microscopy of the trichome wing cells showing the presence of endoplasmatic reticulum (arrowhead). Asterisks indicate cytoplasmic content (a-c). 
Table 1 - Histochemical tests in trichome wing cells of Vriesea.

\begin{tabular}{llll}
\hline & V.tijucana & V.platynema var. platynema & V.platynema var. variegata \\
\hline Tetrazolium test & Weakly red & Weakly red & Weakly red \\
Neutral red & Red & Red & Red \\
Evan's Blue & Negative & Negative & Negative \\
Fuchsine & Slightly fucsin & Slightly fucsin & Slightly fucsin \\
Phloroglucin & Negative & Negative & Negative \\
\hline
\end{tabular}

these wing cells. This also indicates that the cells didn't show membrane fragmentation, e.g., they were alive (Fig. 2d). In addition, we could see the nuclei slightly stained in purple, indicating that these cells were not empty. Blue toluidine test highlighted the cytoplasmic content present in the cells (Fig. 2c). The results of the above mentioned tests are summarized in Table 1.

In longitudinal view, the trichome is observed to be inserted in a depression in the epidermis and to be supported by a single-series pedicel that emerges from two basal cells anticlinally juxtaposed. The apical cell of the pedicel is bigger than the others and has a triangular to rounded shape. The intermediate cells are periclinally flat, their periclinal cellulosic walls are slightly thinner, and the cytoplasmic content is present. The basal cells have a regular shape and are slightly periclinally elongated in a transverse view of the leaf. The number of cells in the pedicel ranges from three to five in Vriesea platynema var. platynema and in V.platynema var. variegate, and from five to six in $V$. tijucana (Figs. 1c,e,h).

With the use of Transmission Electron Microscopy (TEM), we could analyze the wing's trichome cell content at its maturity. At this stage, endoplasmic reticulum (ER) is present in wing trichome cells, indicating that these cells are alive (Fig. 2f). Using TEM, we could also observe that the walls of wing's trichome cell have only a primary thickening, which supports the results obtained with acid phoroglucin reaction.

\section{Discussion}

Studies on Bromeliaceae reveal that the system of foliar trichomes is fundamental for the absorption of water and nutrients in plants with small roots, and it is also an essential characteristic to the success of epiphytes (Pittendrigh 1948). Tillandsioideae has specialized trichomes divided into mesophytic and atmospheric forms. The frequency of trichomes in Tillandsioideae is nearly fourfold greater when compared to other subfamilies. The diameter of the trichome's pedicel is nearly twofold greater in the atmospheric form (Benzing 1976). According to Tomlinson (1969), species that have a larger number of wing cells and larger trichome wings are more specialized for epiphytism, especially those with a lateral, asymmetric prolongation, known as a "dew tongue". This structure was described in atmospheric species of the genus Tillandsia L. that do not have a rosette (Tomlinson 1969). The trichomes observed in the genus Vriesea are those of the mesophytic form, in which the wings are circular. This form of trichome is considered to be an ancestor form on the phylogenetic scale in relation to atmospheric trichomes (Tomlinson 1969).

The taxa studied here are epiphytes that show a well-developed rosette and primarily fixating roots. It is therefore believed that the absorptive function of the peltate trichomes is fundamental to the nutrition of the plant. According to Benzing, Seemann \& Renfrow (1978), peltate trichomes also perform the function of reflecting light, which is associated with their flexibility: When positioned flat on the leaf surface in a humid environment, the reflective capacity is low, but when the wing cells are flexed upwards in a dry environment, they have a high capacity for dispersing light, thereby diminishing the plant transpiration.

Benzing et al. (1976), Tomlinson (1969) and Strehl (1983) state that the Tillandsioideae trichomes are organized and symmetrical when observed in front view. The authors also state that Tillandsioideae trichomes have four central cells and eight pericentral cells, and may or may not have a subperipheral ring. Moreover, the cell number of the wing ranges from 32 to 64. According to Haberlandt (1914), Tomlinson 
(1969) and Benzing et al. (1976), all wing cells are devoid of living content. However, Strehl (1983) states that the central cells of the disk are alive and the other cells of the wing are dead. In a recent study, Derwidueé \& Gonzales (2010) analyzed the leaf anatomy and ontogeny of trichomes in 31 species of Bromeliaceae, including species of the genus Vriesea, and found that the cells of the peltate portion undergo apoptosis when mature and the wing cells are the first to become dehydrated and collapse. In the present study, cytoplasmic content was found in the wing cells of Vriesea tijucana. The positive result for the tetrazolium test and negative result for Evan's Blue test indicated that the cells are alive. Some central and pericentral cells also exhibited cytoplasmic content.

Regarding the water absorption process in Tillandsioideae, Benzing et al. (1976) and Benzing (1976) affirm that water fills the cells of the wing, straightening the lateral walls of the four central cells and forcing the outer tangential wall upwards, thereby allowing the cell cavity to expand. Following the swelling of the central cells, the wing cells of the trichome are flexed downwards against the leaf surface. This combination of central cell expansion and downward flexion of the wing cells produces suction, thereby draining more water under the wing to the central cells. The water is transported by osmosis, passing through the cells of the pedicel and reaching the mesophyll.

Studies carried out by Dolzmann (1964, 1965), as cited by Benzing et al. (1976), describe the elaborate ultrastructure of the apical cell of the trichome's pedicel in Tillandsioideae, including an invaginated plasma membrane and numerous mitochondria, suggesting an absorptive function. The same has not been described in other subfamilies.

In a study on the ontogeny of the trichomes observed in Aechmea nudicaulis (L.) Griseb., Neoregelia cruenta (Graham) L.B.Sm. and Vriesea neoglutinosa Mez, Mantovani \& Iglesias (2005) report that the cells of the disc and scales of the wing are dead and empty when completely formed. According to these authors, these dead cells perform capillary action, storing water in their lumens, which then comes into contact with the leaf surface.

Papini et al. (2010) studied the development of trichomes in Tillandsia aeranthos (Loiseleur) L.B.Sm. with the use of Scanning Electron
Microscopy (SEM) and Transmission Electron Microscopy (TEM). They observed that close to its maturity, these cells appeared to be empty and to have pores on their walls. In the species of Vriesea studied here, we were able to observe content inside these cells by using optical microscopy. The negative results for Evan's Blue test show that the membrane is not fragmented and the cell wall does not have pores. Additionally, due to the results obtained through TEM analysis showing the presence of ER in the wing cells of the trichome we can infer that these cells are alive.

Recent studies carried out by Aoyama \& Sajo (2003), Proença \& Sajo (2004, 2007), Scatena \& Segecin (2005), Souza et al. (2005), Monteiro, Forzza \& Mantovani (2011), Silva, Oliveira \& Scatena (2011) and Mantovani et al. (2012) describe absorbent peltate trichomes in different genera of Bromeliaceae, but make no reference to the content of these cells. Moreover, an anatomic study on species of the genus Vriesea carried out by Arruda \& Costa (2003) mentioned the presence of cytoplasm in the wing cells. However, the authors do not discuss this feature and its implications.

As the absorption model proposed by Benzing et al. (1976) considers the cells of the wing to be dead, further studies are needed in order to determine whether the presence of living cells in the wing exerts an influence on the absorption dynamics. These cells could absorb water from the environment and transmit it cell to cell by osmosis. However, more studies need to be undertaken in order to elucidate these mechanism.

\section{Acknowledgement}

We are thankful to the Brazilian National Counsel of Technological and Scientific Development (CNPq) and to the Brazilian Coordination, for the Improvement of Higher Education Personnel (CAPES) for the Master's degree scholarships provided to the first and the third authors, respectively.

\section{References}

Aoyama, E. \& Sajo, M. 2003. Estrutura foliar de Aechmea Ruiz \& Pav. Subgênero Lamprococcus (Beer) Baker e espécies relacionadas (Bromeliaceae). Revista Brasileira de Botânica 26: 461-473.

Arruda, R. \& Costa, A. 2003. Foliar anatomy of five Vriesea sect. Xiphion (Bromeliaceae) species. Selbyana 24: 180-189. 
Baker, C. \& Mock, N. 1994. An improved method for monitoring cell death in cell suspension and leaf disc assays using Evans Blue. Plant Cell, Tissue and Organ Culture 39: 7-12.

Benzing, D. 2000. Bromeliaceae: profile of an adaptative radiation. Cambridge Press, New York. $714 \mathrm{p}$.

Benzing, D. 1976. Bromeliad trichomes: structure, function and ecological significance. Selbyana 1: 330-348.

Benzing, D.; Henderson, K.; Kessel, B. \& Sulak, J. 1976. The absortive capacities of bromeliads trichomes. American Journal of Botany 63: 10091014.

Benzing, D.; Seemann, J. \& Renfrow, A. 1978. The foliar epidermis in Tillandsioideae (Bromeliaceae) and its role in habitat selection. American Journal of Botany 65: 359-365.

Berlyn, G. \& Miksche, J. 1976. Botanical microtechnique and cytochemistry. The Iowa State University, Iowa. 326p.

Braga, M. 1977. Anatomia foliar de Bromeliaceae da Campina. Acta Amazonica 7: 1-74.

Brasil. 2009. Regras para análise de sementes. Ministério da Agricultura, Pecuária e Abastecimento. Secretaria de Defesa Agropecuária. Mapa/ACS, Brasília. 395p.

Derwidueé, F. \& Gonzalez, A. 2010. Anatomía foliar em Bromeliaceae del nordeste Argentino y Paraguay. Bonplandia 19: 153-173.

Gibbons, I. \& Grimstone, A. 1960. On flagelar structure in certain flagellates. Journal of Biophysic and Biochemistry 7: 679-716.

Gilmartin, A. \& Brown, G. 1987. Bromeliales, related monocots, and resolution of relationships among Bromeliaceae subfamilies. Systematic Botany 12: 493-500.

Haberlandt, G. 1914. Physiological plant anatomy. Macmillan Co, London. 779p.

Johansen, D. 1940. Plant microtechnique. McGraw-hill Book Co., New York. 523p.

Kaiser, E. 1880. Verfahren zur herstellung einer tadellosen glycerin-gelatine. Botanisch Zentralb 180: 25-26.

Krauss, B. 1949. Anatomy of the vegetative organs of the Pineapple, Ananas comosus (L.) Merr. II - The leaf. Botanical Gazette 110: 333-404.

Kraus, J. \& Arduin, M. 1997. Manual básico de métodos em morfologia vegetal. Edur, Seropédica. 198p.

Luther, H. 2012. An alphabetical list of bromeliad binomials. $12^{\text {th }}$ ed. The Bromeliad Society International. The Marie Selby Botanical Gardens. Sarasota \& Bromeliad Society International, Sarasota. 44p.

Mantovani, A. \& Iglesias, R. 2005. Quando aparece a primeira escama? Estudo comparativo sobre o surgimento de escamas de absorção em três espécies de bromélias terrestres de restinga. Rodriguésia 56: 73-84.

Mantovani, A.; Venda, A.; Almeida, V.; Costa, A. \& Forzza, R. 2012. Leaf anatomy of Quesnelia (Bromeliaceae): implications for the systematics of core bromelioids. Plant Systematics and Evolution 298: 787-800

Martinelli, G.; Vieira, C.; Gonzales, M.; Leitman, P.; Piratininga, A.; Costa, A. \& Forzza, R. 2008. Bromeliaceae da Mata Atlântica Brasileira: lista de espécies, distribuição e conservação. Rodriguésia 59: 209-258.

Mez, C. Bromeliaceae. 1896. In: Candolle, ALPP. de et Candolle, ACP. de (eds.). Vol. 9. Monographiae Phanerogamarum. G. Masson, Paris. Pp. 1-990.

Monteiro, R.; Forzza, R. \& Mantovani, A. 2011. Leaf structure of Bromelia and its significance for the evolution of Bromelioideae (Bromeliaceae). Plant Systematics and Evolution 293: 53-64.

O’Brien, T.; Feder, N. \& McCully, M. 1964. Polychromatic staining of plant cell walls by toluidine blue. Protoplasma 59: 368-373.

Papini, A.; Tani, G.; Di Falco, P. \& Brighigna, L. 2010. The ultrastructure of the development of Tillandsia (Bromeliaceae) trichome. Flora 205: 94-100.

Pereira, T.; Oliveira, T.; Silva, L. \& Azevedo, A. 2011. Comparative leaf anatomy of four species of Bromelioideae (Bromeliaceae) ocurring in the Atlantic Florest, Brazil. Botany 89: 243-253.

Pittendrigh, C. 1948. The Bromeliad - Anopheles Malaria complex in Trinidad. I-The Bromeliad flora. Evolution 2: 58-89.

Proença, S. \& Sajo, M. 2004. Estrutura foliar de espécies de Aechmea Ruiz \& Pav. (Bromeliaceae) do Estado de São Paulo, Brasil. Acta Botânica Brasílica 18: 319-331.

Proença, S. \& Sajo, M. 2007. Anatomia foliar de bromélias ocorrentes em áreas de cerrado do Estado de São Paulo, Brasil. Acta Botânica Brasilica 21: 657-673.

Reynolds, E. 1963. The use of lead citrate at high $\mathrm{pH}$ as an electron-opaque stain in electron microscopy. Journal of Cell Biology 17: 208-12.

Ruzin, S. 1999. Plant Microtechnique and Microscopy. Oxford University Press, Oxford. 320p.

Scatena, V. \& Segecin, S. 2005. Anatomia foliar de Tillandsia L. (Bromeliaceae) dos Campos Gerais, Paraná, Brasil. Revista Brasileira de Botânica 28: 635-649.

Schimper, A. 1888. Die epiphytische Vegetation Amerikas. Gustav Fischer, Jena. 194p.

Silva, I. \& Scatena, V. 2011. Anatomia de raízes de nove espécies de Bromeliaceae (Poales) da região amazônica do Estado de Mato Grosso, Brasil. Acta Botanica Brasilica 25: 618-627. 
Silva, I.; Oliveira, D. \& Scatena, V. 2011. Anatomia foliar de Ananas ananassoides (Baker) L.B.Sm., Vriesea bituminosa Wawra e Guzmania lingulata (L.) Mez (Bromeliaceae) do parque Estadual Cristalino, Alta Floresta-MT, Brasil. Revista de Ciências Agro-Ambientais 9: 83-95.

Smith, L. \& Downs, R. 1974. Pitcairnioideae (Bromeliaceae). Flora Neotropica. Hafner Press, New York. 658p.

Souza, G.; Estelita, M. \& Wanderley, M. 2005. Anatomia foliar de espécies brasileiras de Aechmea subg. Chevaliera (Gaudich. ex Beer) Baker, Bromelioideae-Bromeliaceae. Revista Brasileira de Botânica 28: 603-613.
Spurr A. 1969. A low-viscosity epoxy resin embedding medium for electron microscopy. Journal of Ultrastructure Research 26: 31-43.

Strhel, T. 1983. Forma, distribuição e flexibilidade dos tricomas foliares usados na filogenia de Bromélias. Iheringia-Série Botânica 31: 105-119.

Tietze, M. 1906. Physiologische Bromeliaceen Studien II. Die Entwicklung der wasseraufnehmenden Bromeliaceen - Trichome. Z. Naturwissen 78: $1-50$.

Tomlinson, P. 1969. Commelinales-Zingiberales. In: Metcalf, CR. (ed.). Anatomy of the monocotyledons: III. Claredon Press, Oxford. Pp. 193-294. 